\title{
THE VALUE OF STANDARDS IN TEACHING ARITHMETIC.
}

By G. W. Finley, Colorado State Teachers College, Greeley, Colo.

There are in general two main reasons for teaching arithmetic in the modern school: first, to make the children reasonably proficient in the fundamentals of number, and second, to give them training in the mathematical type of reasoning. Practically all teachers will agree that these two aims should always be kept in mind and that they must both be realized if efficient teaching is to be done. The teacher who fails in either is only half successful.

While both of these aims in teaching arithmetic, then, are important they are by no means equally easy of attainment. The first is by far the easier; so much so, in fact, that no teacher however lacking in special ability need fail here. This is not true of the training in reasoning. We cannot hope for satisfactory results in this kind of training until we have teachers specially prepared to do work along this line. But in spite of the fact that training in the fundamentals of number work is so simple a very little testing of children in the schools will convince any one, if indeed he is not already convinced, that even here teachers are failing to a lamentable degree. There are undoubtedly a good many contributory causes but I am convinced that chief among them all is lack of definite aims and standards on the part of teachers.

Ask almost any teacher how her children. stand in the matter of speed and accuracy in arithmetic and she. will answer that they are "fairly good" or "not very good," or give some other" equally indefinite answer. Ask her if they are improving and she will answer still more indefinitely, "I believe so" or "I hope so." The trouble is she has no definite aim in view and no definite standards with which to compare her pupils, either as to present ability or as to progress made.

This is an unfortunate state of affairs, and an entirely unnecessary one. In the teaching of the fundamentals we can and should be as definite in our aims as are our colleagues in the business department in the teaching of typewriting. They work in no haphazard, hit or miss fashion. They have in mind at the beginning of the year just how many words a pupil should be able to write in a minute at the end of the year, and they work steadily and consistently to reach that standard. In the same 
way every teacher of arithmetic should know just how many addition combinations her pupils should be able to write in a minute by the end of the year and should work steadily and persistently to reach that standard. So also with subtraction, multiplication, and division.

As to what the standards for the various grades should be we are fortunate in having at our command the results of the work done by such men as Rice, Stone, and Courtis. Mr. Courtis, after averaging tests from several thousand children, gives the following table:

STANDARD SCORES.

\begin{tabular}{|c|c|c|c|c|c|c|c|c|c|c|}
\hline \multirow[b]{2}{*}{ No. OF Test. } & \multirow[b]{2}{*}{ No. 1} & \multirow[b]{2}{*}{ N'o. 2} & \multirow{2}{*}{$\begin{array}{r}\text { Nos. } \\
3 \& \& 4\end{array}$} & \multirow[b]{2}{*}{ No. 5} & \multicolumn{2}{|c|}{$\mathrm{No.6}$} & \multicolumn{2}{|c|}{ No. 7} & \multicolumn{2}{|c|}{ No. 8} \\
\hline & & & & & Ats. & Rt. & Āts. & Rt. & Ats. & Rt. \\
\hline Grade 3 & 26 & 19 & 16 & 58 & 2.7 & 2.1 & 5.0 & 2.7 & 2.0 & 1.1 \\
\hline Grade 4 & 34 & 25 & 23 & 72 & 3.7 & 3.0 & 7.0 & 3.3 & 2.6 & 1.7 \\
\hline Grade 5 & 42 & 31 & 30 & 83 & 4.8 & 4.0 & 9.0 & 4.9 & 3.1 & 2.2 \\
\hline Grade 6 & 50 & 38 & 37 & 99 & 5.8 & 5.0 & 11.0 & 6.6 & 3.7 & 2.8 \\
\hline Grade 7 & 58 & 44 & 44 & 110 & 6.8 & 6.0 & 13.0 & 83 & 4.2 & 3.4 \\
\hline Grade 8 & 63 & 49 & 49 & 117 & 7.8 & 7.0 & 14.4 & 10.0 & 4.8 & 4.0 \\
\hline Grade 9 & 65 & 50 & 50 & 120 & 8.6 & 7.8 & 15.0 & 11.0 & 5.0 & 4.3 \\
\hline
\end{tabular}

These tests covered the following ground:

Test No. 1. Addition.

Test No. 2. Subtraction.

Test No. 3. Multiplication.

Test No. 4. Division.

Combinations $0-9$.

Test No. 5. Copying figures (rate of motor activity.)

Test No. 6. Speed reasoning (simple one-step problems showing number attempted and number right.)

Test No. \%. Fundamentals combined (abstract examples in the four fundamental operations.)

Test No. 8. Reasoning (two-step problems.)

These tests are exceedingly simple and can be given by any teácher without any special drill in this sort of work. To be of any use in determining standards they must be given to all the different grades, or to any one grade at different times, under exactly the same conditions. The exercises are printed or written on separate sheets of paper, one copy for each child, and placed face down on the desks of the children to be tested. At a given signal the children turn these sheets over and write as many answers as possible in the time allowed. Each sheet has more exercises on it than the swiftest child can complete in the time given. 
Each of these tests consists of a sheet of exercises similar to the following:

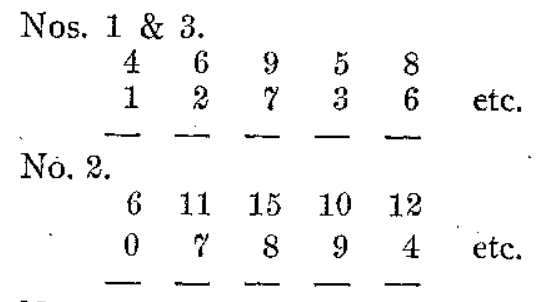

No. 5.
1) 8
5) 30
8) 72 1) 0
9) 36
2) 6 etc.

No. 6 .

$$
\begin{array}{llllllll}
2 & 4 & 9 & 6 & 7 & 4 & 2 & \text { etc. }
\end{array}
$$

1. The children of a school gave a sleigh-ride party.

There were 9 sleighs used and each sleigh held 30 children. How many children were in the party?

2. Two school girls played a number game. The score of the girl that lost was 57 points and she was beaten by 16 points. What was the score of the girl that won? etc.

(These problems are not to be solved. The children are to read them and write down the name of the operation to be used, addition, subtraction, multiplication, division.)

No. \%.

No. 8.

1. $6154+312+5800+4003+3020+265$.

2. 63210132- 48676392 .

3. $46608 \times 345$.

4. $3128102 \div 453$, etc.

1. A party of children went from a school to a woods to gather nuts. The number found was but 205 , so they bought 1955 nuts more from a farmer. The nuts were shared equally by the children and each received 45 . How many children were there in the party? etc.

(Problems to be solved.)

The time allowances for these tests were as follows: Tests Nos. $1,2,3,4,5$ and 6 , one minute each; Test No. 7 , twelve minutes; Test No. 8, six minutes. Complete copies of the original Courtis tests may be obtained from S. A. Courtis, Detroit. Mich. 
The teacher who has before her some such defunite standards as those set forth by. Mr. Courtis and who finds out just where her pupils stand in the various abilities by applying such tests as those suggested here will then be in a position to do efficient work so far as training in the fundamentals is concerned. But so long as teachers have no standards with which to compare, and no definite aims toward which to work, so long shall we continue to hear that dismal refrain "Our public schools are a colossal failure," in so far, at least, as efficiency in the fundamentals of number work is concerned.

The thing of first importance, then, for any teacher or supervisor of arithmetic is to apply standard tests and find out what is needed. The next thing is to set to work deliberately and systematically to drill the pupils in the lines of work they need most. A fundamental principal here is, To secure improvement in any specific line of work, drill in that line. In other words if you want to get improvement in the addition combinations the surest and most economical way to get it is to drill on the addition combinations. Do not depend upon getting results indirectly. Drill exercises should of course be short, from three to five minutes, but they should be regular, daily if possible.

The results of such definite, systematic drill will be marked and immediate, both in improvement in the character of the work done and in the interest shown. Children like to do what they can do well and the teacher who sets up standards and helps her pupils to work toward them will be rewarded not only by seeing definite improvement in the work of the class, but by finding a new enthusiasm springing up in the children for work that they have been at least indifferent about before.

I have confined myself for the most part in this discussion to the teaching of fundamentals, not because it is the more important of the two reasons named in the outset for the teaching of arithmetic, but because it is the one most easily attained and the one in which the greatest amount of improvement may be made by the setting up of definite standards. No teacher is justified in working for this alone, but every teacher should bring her children to a reasonable degree of efficiency in the fundamentals whether she does anything else in her arithmetic teaching or not. If this can be done we will at least have delivered ourselves from the charge that we do not even teach the children to "cipher" correctly. 